胃悪性リンパ腫を合併した胃サルコイドーシスの 1 例

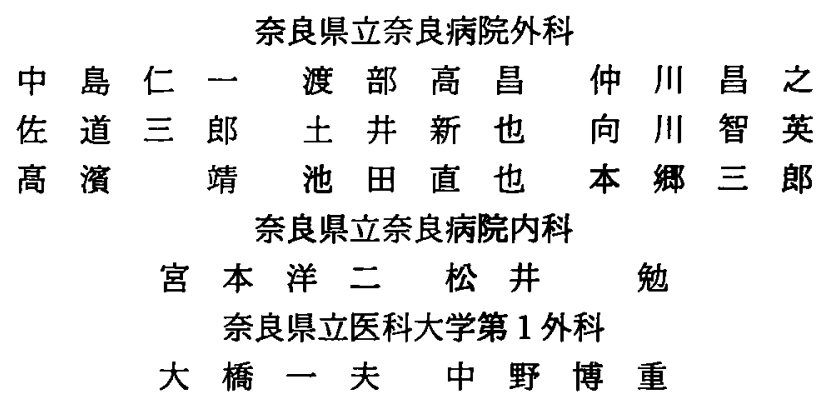

胃原発性非ホジキンリンパ腫を合併した胃サルコイドーシスの 1 例を経験した。

症例は 40 歳, 男性. 平成 3 年 6 月, 上腹部不快感, 嘔気, 嘔吐を主訴に当院受䛦. 多 発性胃潰場の診断にて経過観察されていた。平成 6 年11月, 潰瘍部の生検が行われ, 胃 悪性リンパ腫と診断されたため, 当科にて胃全摘術および D2リンバ節郭清を施行した. 病理組織学的に, 胃のほほ全域と所属りンパ節より, ラングハンス型巨細胞を伴う類上 皮細胞からなるサルコイド結節を認め, また胃体部の 3 カ所から粘膜下層に浸潤する悪 性リンパ腫を認めた。サルコイドーシスと悪性リンパ腫の合併は, 欧米では比較的多く 報告されているが, 本邦では少なく，また両疾患が胃に限局されており極めて稀な症例 と考えられた。

索引用語：胃サルコイドーシス, 胃悪性リンパ腫, sarcoidosis-lymphoma syndrome

\section{緒 言}

サルコイドーシスに悪性リンパ腫が合併すること は，欧米では比較的多く報告されているが，両疾患が 胃に限局した報告は極めて稀である.今回われわれは， 胃サルコイドーシスに胃悪性リンパ腫を合併した症例 を経験したので，両疾患の病因発生につき，文献的考 察を加えて報告する。

\section{症例}

症例：40歳, 男性.

主訴：上腹部不快感。

家族歴：特記すべきことなし，

既往歴：20歳, 急性虫垂炎.

現病歴: 平成 3 年 6 月頃より上腹部不快感, 食後喝 気，咞吐を自覚するようになったため，平成 3 年 6 月, 当院内科受診. 胃内視鏡にて多発性胃謴瘍との診断を 受け，外来通院をしていた。平成 6 年 8 月, 会社の健 康猃断で胃内視鏡が行われ，胃体後壁の潰鹪部周辺の

1995年10月23日受付 1996年 4 月16日採用
胃粘膜の生検より，胃悪性リンパ腫の疑いありとの診 断を受け, 精查・加療目的のため, 同年10月21日当院 内科入院. 手術目的にて11月22日外科転棟となる。

入院時現症：身長 $180 \mathrm{~cm}$, 体重 $80 \mathrm{~kg}$, 血压 $124 / 80$ $\mathrm{mmHg}$, 脈拍数66整, 栄養状態良好, 眼球結膜に黄染 なく, 眼瞼結膜に負血を認めない, 胸部打聴診上異常 なく, 腹部は平坦軟であり, 肝・脾・表在リンパ節は 触知しなかった。

入院時検查成績：末梢血血算，生化学，尿検查にて 特に異常を認めなかった. 腫瘍マーカーcarcinoembryonic antigen (CEA) も正常篹用内であった.

胸部単純 $\mathbf{X}$ 線所見：両側肺門部リンパ節腫脹を認 めず，肺野にも異常を認めなかった（図 1)。

胃 X 線所見：背卧位二重造影で, 特に謴瘍性病変を 指摘されず,胃壁の伸展性も良く保たれていた(図2).

胃内視鏡所見：胃粘膜は全体的に浮腫状であり，胃 体中部から上部前後壁に白苔を伴った不整形の浅い海 瘍性病変を認めた。周堤は明らかではなく, 易出血性

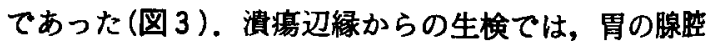




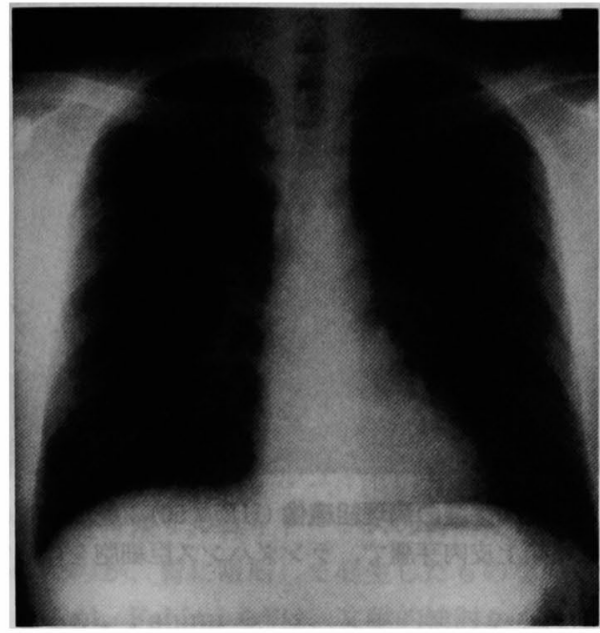

図 1 胸部 $\mathbf{X}$ 線正面像：肺門部リンパ節腫脹はなく, 肺野にも特に異常を認めない.

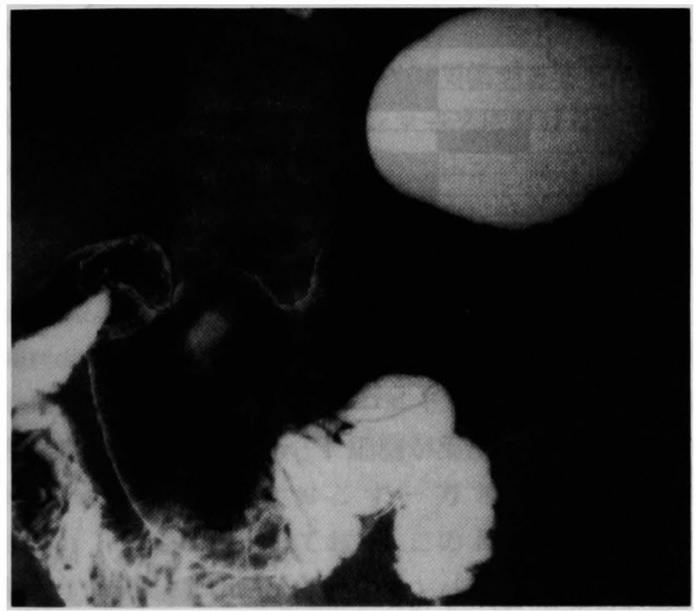

図 2 胃透視所見：潰瘍性病変は特に認めず, 胃壁の 伸展性も良好であった。

構造は消失し, 粘膜内にびまん性に増殖する大型の均 一な腫瘍細胞を認めた. 免疫染色にて, CD45 (LCA) 陽性, B 細胞抗原陽性, $\mathrm{T}$ 細胞抗原陰性であった。

以上の所見より, 悪性リンパ腫, diffuse large B cell type と診断し, 手術を施行した。

手術所見：平成 6 年11月30日, 上腹部正中切開によ る開腹手術を行った. 術中所見では, 腹膜・肝・脾に 異常はみられなかったが No. 3,4および 6 の所属りン パ節に腫脹を認めた。 また，腫瘍は触知せず，墏膜浸 潤も陰性であった.胃全摘術およびD2リンパ節郭清を 施行した。

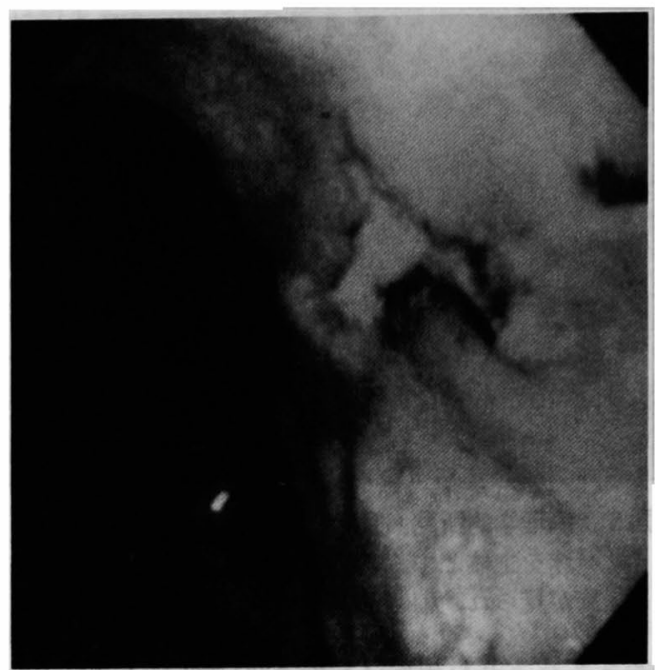

図 3 胃内視鏡所見：胃体上中部前後壁に白苔を伴っ た不整形の浅い潰瘍性病変を認めた.

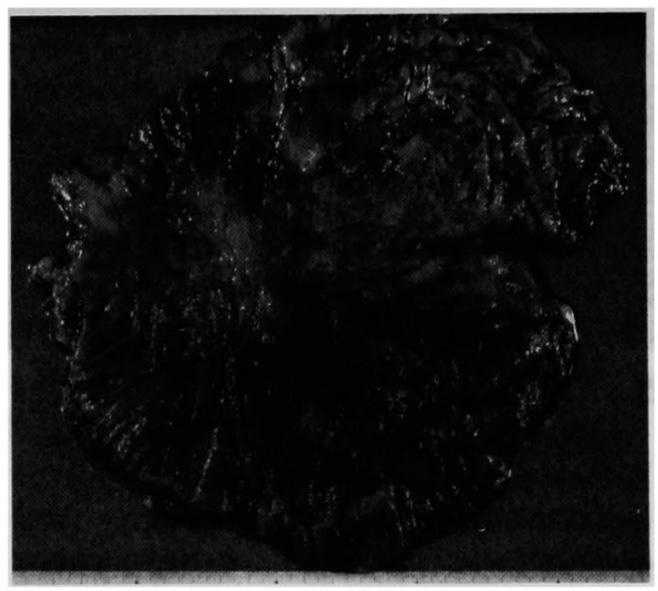

図 4 新鮮切除標本 : 胃粘膜全体に発赤が強く, 胃体 部に潰瘍痏痕が見られた。

切除標本肉眼所見：胃体部に潰瘍疫痕がみられた。 また, 粘膜全体に発赤が強く, 特に穹薩部から胃体上 部にかけては, 胃壁の肥厚が目立った（図4）.

病理組織学的所見: 切除された胃を全割し組織標本 として検索した. ほとんどすべての切片の粘膜から粘 膜下層にかけて, 高度のリンパ球, 好中球, 形質細胞 などの結節状の集簇がみられた。この部分の遊離細胞 で flow cytometry を行ったところ, surface $\operatorname{Ig} \lambda$ 陽性 細胞に比べ, surface $\operatorname{Ig} \boldsymbol{x}$ 陽性細胞の比率が高いもの の, $x / \lambda$ 比はおよそ1.5であり, monoclonality は存在 しなかった. 反応性リンパ滤胞增生 (reactive 


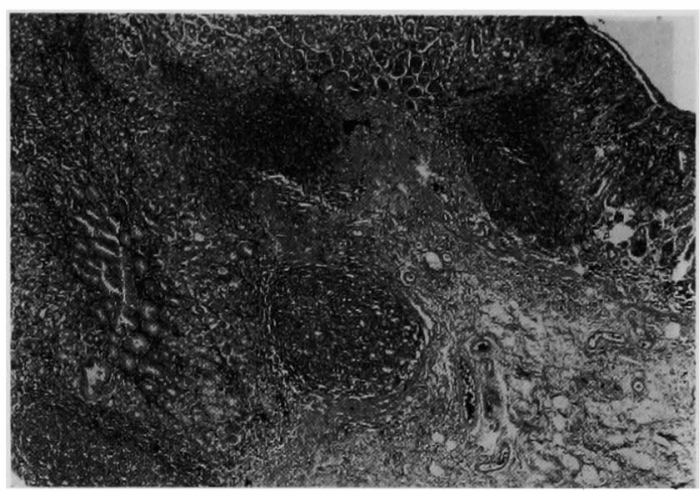

図 5 病理学的所見 $(\mathrm{HE} \times 40):$ 粘膜内を中心に, リ ンパ球を主体とする炎症細胞の浸潤と, リンパ球の 集族が見られ，免疫組織学的に RLH と診断された.

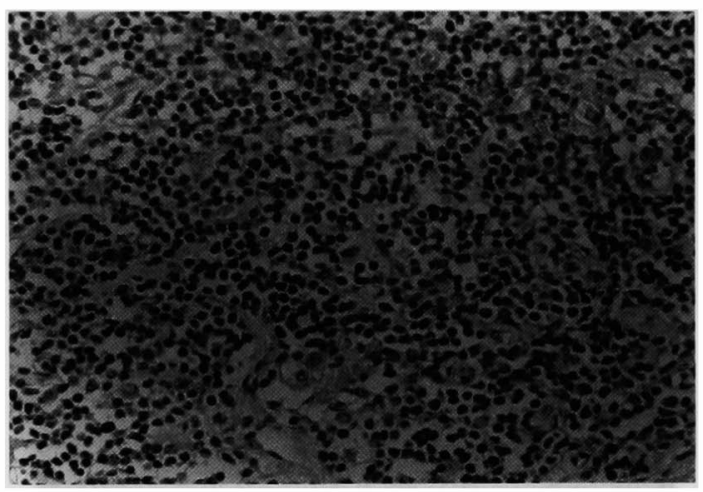

図 6 病理学的所見 $(\mathrm{HE} \times 100):$ 大型のリンパ球系 細胞のびまん性増殖を認め, 胃粘膜下層に浸潤して いた.

lymphoreticular hyperplasia : 以下, RLH と略記) と 考えられた(図 5 )。また，胃体中下部の計 3 力所より 核異型の軽度な大型のリンパ球系細胞のびまん性増殖 を認めた. 腫瘍はそれぞれ長径約 $5 \mathrm{~mm}$ であり, 腫場細 胞はわずかに粘膜下層に浸潤性増殖を示していた。核 分裂像および apoptosis を伴い, 先の RLH とは異 なった増殖様式であり,胃悪性リンパ腫と診断した(図 6 ). Working Formulation で non-Hodgkin, intermediate grade, diffuse, large cell type, large noncleaved cell subtype であった.さらに，胃壁のほほ全 域に多くの肉芽結節を認めた。個々の結節は乾酪壊死 のみられない類上皮肉芽腫で，ラングハンス型巨細胞 を交えていた(図 7). 肉芽結節のみられる層には一定 の傾向はみられず，全層に及んでいた(図 8 )。郭清さ れたリンパ節18個すべてに無数の肉芽結節がみられ

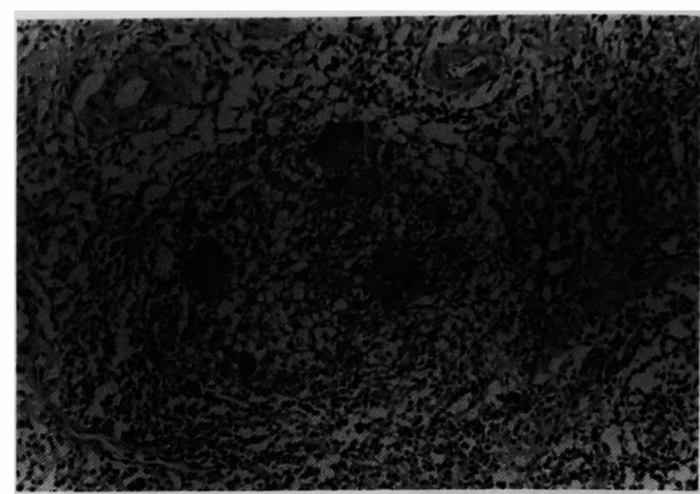

図 7 胃肉芽腫の病理組織像 $(\mathrm{HE} \times 50)$ : 乾酪壊死の ない類上皮肉芽腫で, ラングハンス巨細胞を伴って いた.

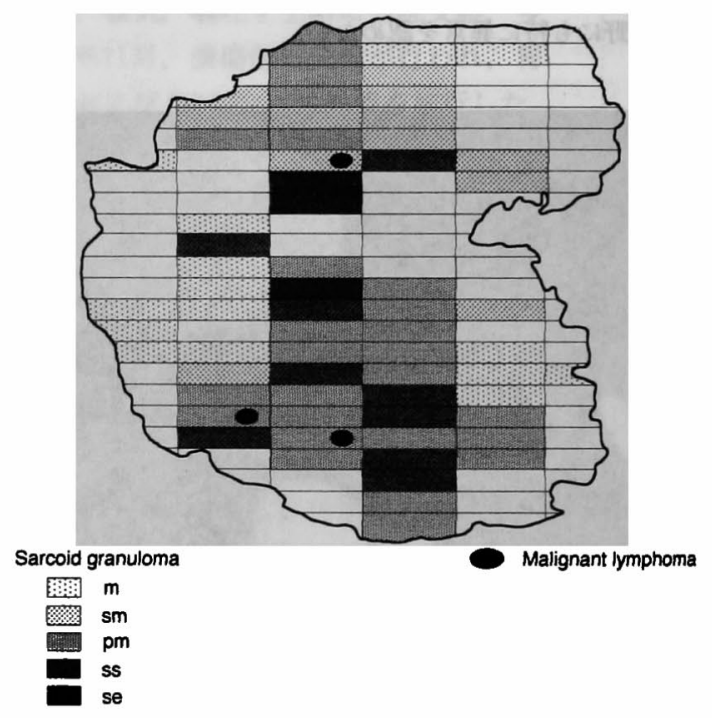

図 8 肉芽結節およびリンパ腫の分布図：リンパ腫は 胃体部の 3 力所に存在し, 肉芽結節は全層に散在し ていた。

た．抗酸菌染色では結核菌は陰性であった。これより 胃サルコイドーシスが最も考えられた。

術後, ツベルクリン反応 $21 \times 16 \mathrm{~mm}$, 血清アンギオテ ンシン変換酵素 $208 \mathrm{IU} / / / 37^{\circ} \mathrm{C}$, 注腸検査では特に Crohn 病を示唆するような異常所見はなく, 眼科検査 にても眼底に異常所見は認めなかった.

以上より，最終的に胃悪性リンパ腫を伴った胃サル コイドーシスと診断した.

なお, 術後 CHOP 療法 (cyclophosphamide $800 \mathrm{mg}$, day 1 /epirubicin $60 \mathrm{mg}$, day 1 /vincristine $2.0 \mathrm{mg}$, 
day $1 /$ predonizolone $20 \mathrm{mg} / \mathrm{d}$, day 1-5) を 2 クール 行い，全身状態に著変なき事を確認のうえ退院となっ た. 現在, 悪性リンパ腫の再発を認めることもなく， 外来にて経過観察中である.

\section{考 察}

消化管に肉芽腫を形成する疾患には，結核，梅毒， 真菌疾患, 巽物, サルコイドーシス, Crohn 病, リン パ增殖性疾患, 癌による反応性病変などがある”。この うち，サルコイドーシスは，類上皮細胞肉芽腫を形成 する原因不明の疾患である゙が，胃に発生することは 比較的稀である．胃にサルコイド肉芽腫をみた場合， それが, 全身性サルコイドーシスの胃病変としての一 部分症なのか, 胃に限局して発生したものなのかが問 題となるが, Fahimi らは, 文献的検討から, 後者を isolated granulomatous gastritisとしてひとつの疾 患単位とみることを提唱した。

サルコイドーシスに種々の悪性疾患が合併すること が報告されている゙!．中でもサルコイドーシスと悪性 リンパ腫の合併は，欧米では因果関係があるとする意 見が多い. Brincker ららはデンマークにおける調查で， サルコイドーシス患者では, 悪性リンパ腫の発生率は 一般集団よりも有意に高く期待值の11倍を示したと報 告した。 また, Brincker は, 17例の自験例と29例の過 去の報告例を検討し，両者に因果関係を見出し， sarcoidosis-lymphoma syndrome という概念を提唱 した6). Daniele ら゙は,サルコイドーシスにおいて, 肉 芽腫性病変部に helper $\mathrm{T}$ 細胞が集䅡し，B 細胞系の hyperactivityをひきおこす一方で，末梢血中の helper T 細胞は減少しており，このような免疫学的な 異常な状態が続くことによりリンパ球の悪性化の危険 性が高まると述べている.一方, 泉ら゙はサルコイドー シスは臨床的に易感染性, 悪性腫場の頻発など, いわ ゆる兔疫不全状態の徴候を示すことはないと述へてお ク,サルコイドーシスの免疫異常と悪性疾患の発生を 十分説明しうる統一した意見はない。

両疾患の合併例は，多くはサルコイドーシスが先行 している，本症例では，どちらが先行したか詳細は不 明であるが，图8に示すように，悪性リンパ腫の病巣 と肉芽腫性病変の広がりとを比べると, 明らかに肉芽 腫優位であり，胃壁全層に散在していることから，サ ルコイドーシスが先行し，その後胃悪性リンパ腫が発 症した可能性が高いと考えられる。

悪性腫瘍の $4.4 \%$, 悪性リンパ腫の7.3〜 13.8\%にリ ンパ節, 肝荿, 脾藏などにサルコイド反応が生じるこ
とが報告されている゙．悪性腫瘍にサルコイド反応を きたす原因には諸説がある. Nadel ら ${ }^{10}$ は免疫機構の 変化による非特異的な組織反応であるとしている。 た, Gorton ら"1)は腫灏からの代謝産物あるいは分解産 物に対する非特異的な組織反応であると述へている。 いずれにせよ, 宿主側の免疫学的反応に深く関わって いることが予想される. Suen ら ${ }^{12)}$ は悪性腫瘍が先行 し, サルコイドーシスが発症した 6 例をもとに malignancy-sarcoidosis syndrome という概念を提唱 したが，その中で悪性腫瘍やその治療に对して引き起 こされた免疫機構の異常反応が, 結果的にサルコイ ドーシスを引き起こすであろうと述べている。

サルコイドーシスやサルコイド反応は癌に対する生 体防御機構のひとつとも言われている. Syrjanen ら ${ }^{13)}$ は癌が発生した臟器の所属リンパ節にサルコイド肉芽 腫を認めた場合, 癌に対する免疫療法が反応するとき に生ずる肉芽腫と類似していることから，良好な予後 が期待されると述べている。

悪性リンパ腫と RLH の関連について, 毛利 ${ }^{14)}$ は, 低 覀性度のリンパ腫は周囲にRLH を伴うことや, 免疫 組織学的な検索も含めて RLH から 2 次的なリンパ腫 が発生する可能性を述へている. 本症例でも，悪性り ンパ腫の周囲に RLH が伴っており, transformした 可能性が考えられた。

本症例に関し，サルコイドーシスは胃および所属り ンパ節に限局しており，合併した悪性リンパ腫は極め て限局した病変であった。外科的切除により完全に除 去されたこと,さらに術後に化学療法を追加し治療を 一歩進めたことなどにより, 局所の免疫異常反応の有 無に関わらず，非常に良好な予後が期待できるものと 推測される.

\section{結 語}

胃悪性リンパ腫を合併した胃サルコイドーシスの稀 な 1 例を経験したのて, 文献的考察を加えて報告した。 女献

1) David AO, James KK: Disease of the stomach. Atlas of gastrointestinal Pathology. Saunders, Philadelphia, 1994, p35-36

2) James DG, Tarif J, Hosoda T, et al: Description of sarcoidosis. Ann NY Acad Sci 278 : 742, 1976

3) Fahimi HD, Deren JJ, Gottilieb LS, et al: Isolated granulomatous gastritis: Its relationship to disseminated sarcoidosis and regional 
enteritis. Gastroenterology 45: 161-175, 1963

4) 片岡幹男, 中田安成, 飛岡 徹他: サルコイドーシ ス患者における悪性腫瘍発生に関する研究，日胸 疾患会誌 $30: 598-603,1992$

5) Brincker $H$, Wilbek $E$ : The incidence of malignant tumours in patients with respiratory sarcoidosis. Br J Cancer 29 : 247-251, 1974

6) Brincker $\mathrm{H}$ : The sarcoidosis-lymphoma syndrome. Br J Cancer 54 : 467-473, 1986

7) Daniele RP, Dauber JH, Rossman MD: Immunologic abnormalities in sarcoidosis. Ann Intern Med 92: 406-416, 1980

8）泉 孝英, 長井苑子：サルコイドーシスにおける 免疫不全. 医のあゆ $135: 805-810,1975$

9) Brincker $\mathrm{H}$ : Sarcoid reactions in malignant tumours. Cancer Treatment Reviews 13:147-
156,1986

10) Nadel EM, Ackerman LV: Lesions resembling Boeck's saroid in lymphnodes draining an area cantaining a malignant neoplasms. Am J Clin Pathol 20 : 952-957, 1950

11) Gorton G, Linell F: Malignant tumors and sarcoid reactions in regional lymphnodes. Acta Radiol 47 : 381-392, 1957

12) Suen JS, Forse MS, Hyland RH, et al: The malignancy-sarcoidosis syndrome. Chest 98 : 1300-1302, 1990

13) Syrjanen KR: Epitheloid cell granulomas in the lymph nodes draining human cancer. Diagn Histopathol $4: 291-294,1981$

14）毛利 昇：消化管悪性リンパ腫の病理組織学的お よび免疫学的分類. 䟢成人病 $15: 977-982,1985$

\title{
A CASE OF GASTRIC SARCOIDOSIS ASSOCIATED WITH A GASTRIC LYMPHOMA
}

\author{
Masakazu NAKAJIMA, Takaaki WATANABE, Masayuki NAKAGAWA, Saburo SADO, \\ Shinya DOI, Tomohide MUKOUGAWA, Yasushi TAKAHAMA, Naoya IKEDA, \\ Saburo HONGO, Yoji MIYAMOTO*, Tsutomu MATSUI*, \\ Kazuo OHASHI** and Hiroshige NAKANO** \\ Deparment of Surgery and Medicine*, Nara Prefectual Hospital \\ First Department of Surgery**, Nara Medical University
}

We report herein a case of gastric sarcoidosis associated with a Non-Hodgkin's lymphoma. In June, 1991, a 40-year-old man was seen at he hospital because of upper abdominal discomfort, nausea and vomiting and was followed an ambulant basis with a diagnosis of multiple gastric ulcer. In November, 1994, histological examination of the biopsy specimen of the stomach ulcer revealed malignant lymphoma. A total gastrectomy with regional lymph nodes dissection was performed. The resected specimen of the stomach demonstrated erosion and some traces of ulcer. Histopathologically, malignant lymphoma was demonstrated in only a part of the stomach. In contract, gastric sarcoidosis was detected throughout the resected stomach and resected lymph nodes. This case appears interesting from the point of the pathogenesis of malignant lymphoma associated with sarcoidosis, since both the two lesions had been localized to the stomach. Several cases of sarcoidosis together with malignant lymphoma have been reported from the Westren countries, however, gastric sarcoidosis associated with gastric lymphoma is extremely rare, so far. 